\title{
Sosok Etnis-Etnis Minoritas dalam Iklan (Figure of Minority Ethnic in Advertising)
}

\author{
Ruth Mei Ulina Malau \\ (ruth@ftik.usm.ac.id) \\ (Staf Pengajar Jurusan Ilmu Komunikasi Universitas Semarang)
}

\begin{abstract}
Differentiation between minorities and majorities will always be there in the middle of ethnic plurality in Indonesia, and the advertising was succesfully represented it within a spectacle's package in the form of culture's parody, in which figure of minority ethnics are used as an advertising's object to strengthen the colonial [obsession] that leads to the race dichotomy between black and white. Behind the images displayed by advertising, there are hidden minority myths that reveals the life of and the treatment received by minority ethnics in this country. The myths are ultimately based on ideologies of class, race, and language. Figure of minority ethnics, in advertising's package, describes the disorder of Indonesian's human diversity that caused by colonialism and those who inherited the Western civilization.
\end{abstract}

Kata Kunci : Etnis, Minoritas, Mayoritas, Kolonial, Mitos

\section{Pendahuluan}

Bhinneka Tunggal Ika. Unity in Diversity. Satu kesatuan dalam keanekaragaman. Kalimat tersebut mewakili keberadaan bangsa Indonesia yang tercipta dengan keragaman. Indonesia adalah negara, yang secara antropologis dikaruniai lebih dari 500 suku bangsa (ethnic group) dengan ciriciri bahasa dan kultur tersendiri (Marzali, 2005:228). Faktanya, semboyan "berbeda-beda tetapi satu" (Bhinneka Tunggal Ika) tidak lagi ramai dan keras disuarakan akhir-akhir ini, tetapi semboyan itu menyisakan banyak cerita tentang bagaimana kebudayaan diperlakukan selama kurang lebih setengah abad (Abdullah, 2006:63).

Tidak banyak bangsa Indonesia yang menghargai ke-Bhinneka Tunggal Ika-an itu sampai terjadinya kasus yang dianggap sebagai klaim kepemilikan artefak budaya bangsa Indonesia oleh negara lain. Menurut IAIC (Indonesian Archipelago Culture Initiatives), sampai Agustus 2009, sudah 32 artefak budaya Indonesia yang diduga dicuri, dipatenkan, diklaim, dan atau dieksploitasi secara komersial oleh korporasi asing, oknum warga negara asing, atau pun negara lain, 21 di antaranya diklaim oleh Malaysia. Kasus klaim kepemilikan artefak budaya ini memberi keuntungan tersendiri bagi dunia periklanan Indonesia. Berbagai brand menjadi terinspirasi untuk mengangkat tema budaya sebagai ide iklannya. Nilai budaya yang diciptakan oleh sebuah brand dalam iklan menjadi sangat berarti bagi masyarakat, mengingat sebelumnya sangat jarang ditemukan tayangan iklan yang berorientasi pada muatan budaya Indonesia. Beberapa iklan yang mengandung unsur kebudayaan yang kemudian menjadi objek penelitian ini adalah iklan Kuku Bima Energi versi "Papua Sajojo" dan "Kolam Susu", iklan Aqua "Satu dari Kita, Sepuluh untuk Mereka" (7 episode), iklan Visit Indonesia Year 2008 versi "Teaser", iklan Gudang Garam versi "Rumahku Indonesiaku", dan Iklan Teh Botol Sosro versi "Uniknya Negeri". 
Nilai budaya yang muncul dalam iklan tampaknya merepresentasikan ketimpangan Bhinneka Tunggal Ika yang secara tidak disadari telah tercipta di Indonesia. Iklan seolah-olah mengkotak-kotakkan perbedaan antara etnis minoritas dengan etnis mayoritas di Indonesia. Etnis minoritas (minority ethnic) di Indonesia ditujukan pada suku bangsa dengan ciri kulit berwarna hitam dan rambut keriting ikal, sementara etnis mayoritas ditujukan pada suku bangsa yang berkulit 'putih' (dalam artian 'tidak hitam'). Sosok etnik minoritas kini menjadi "ikon" dalam iklan bermuatan budaya, namun kemunculannya tidak terlepas dari kehadiran etnis mayoritas sebagai faktor pembanding. Iklan kemudian memperbesar peluang terciptanya gap di antara etnis minoritas dengan etnis mayoritas, dan mengukuhkan posisi marginal bagi etnis minoritas dalam kerangka kebhinekaan Indonesia.

Perbedaan budaya memang membawa perbedaan nilai kecantikan. Faktanya sebagian besar orang Indonesia terobsesi dengan konstruksi yang dilakukan iklan selama ini, putih adalah cantik, sementara hitam adalah jelek. "Ukuran cantik menjadi salah kaprah, yaitu tinggi, langsing dan putih dengan rambut lurus yang panjang...sementara mereka yang berkulit lebih gelap, gemuk, pendek atau berambut ikal dan keriting merasa kurang menarik..." (Amalia, 2009:6). Dalam konteks kolonialisme, putih menjadi norma. Indonesia, sebagai negara yang telah mengalami kolonialisme selama lebih dari 300 tahun telah ditanamkan pemikiran tentang standar kecantikan, yaitu kecantikan yang putih. Sebagaimana diargumentasikan oleh Jackie Stacey (dalam Prabasmoro, 2003:33), putih merupakan simbol kemurnian, kebersihan, kecantikan, dan kebudayaan yang beradab sementara hitam menyiratkan ketidakmurnian, kekotoran, keburukan dan kebudayaan yang tidak beradab.

Dalam pandangan kultural, keterasingan yang dialami oleh etnis minoritas sebenarnya bukanlah hal yang baru (Wibowo, 2003:210). Etnis kulit hitam senantiasa diasingkan dan dimarginalkan oleh media. Kulit hitam direpresentasikan sebagai jajahan kulit putih dan hal tersebut makin dipertegas oleh media massa melalui iklan. Padahal sebagai sebuah negara Bhinneka Tunggal Ika, Indonesia yang utuh seharusnya Indonesia dari Sabang sampai Merauke, tanpa pembedabedaan dan pengasingan. Namun kenyataannya, media menciptakan jurang pemisah antara kulit hitam dan kulit putih, antara etnis minoritas dan etnis mayoritas, di mana hal ini, mengutip pernyataan Prabasmoro (2003), memperkuat obsesi [kolonial] lama bahwa kulit putih adalah ideal.

Tidak hanya di Indonesia, bentuk penjajahan media terhadap etnis minoritas (kulit hitam) juga terjadi secara global di dunia. Herdiansyah Hamzah menuliskan sebuah catatan berjudul "A Girl Like Me, Diskriminasi Ras Kulit Hitam di Amerika Serikat". Catatan ini menceritakan tentang seorang sineas Amerika, Kiri Davis, yang mengadakan sebuah riset mengenai fakta bagaimana dunia memandang identitas budaya kulit hitam yang didokumentasikan dalam sebuah film berdurasi 7 menit dengan judul "A Girl Like Me". Film dokumenter yang ditayangkan dalam acara televisi Oprah Winfrey edisi "Membongkar Ketabuan" tersebut menceritakan tentang fenomena anak kulit hitam yang termanipulasi dengan masalah diskriminasi warna kulit. Dalam film dokumenter tersebut, Kiri mencoba melakukan riset terhadap beberapa anak kulit hitam (usia 4-6 
tahun), dengan menyodorkan dua buah boneka yang berbeda warna. Boneka pertama berwarna kulit putih dan rambut lurus, sedangkan boneka kedua berwarna kulit hitam dan rambut keriting khas Afrika. Semua sample yang diteliti oleh Kiri memiliki jawaban yang sama dari pertanyaan, "Which one the dolls do you like?-Boneka yang mana yang kamu suka?". Jawabannya satu, "Boneka yang berwarna kulit putih!", dan mereka mengucapkannya tanpa perasaan ragu sedikit pun. Ketika Kiri menanyakan, "Which one the dolls, is the same like you?-Boneka yang mana yang sama seperti dirimu?", mereka dengan penuh rasa malu, ragu dan tertekan, menyodorkan boneka berwarna kulit hitam. Mereka seakanakan telah memperolok-olok dirinya sendiri dengan menyodorkan boneka hitam tersebut. Menyamakan dirinya dengan boneka berwarna hitam, sama dengan menyebut dirinya jelek (http://www.herdiansyah.org/2010/03/gi rl-like-me-diskriminasi-ras-kulit.html).

Ini adalah realitas masyarakat dunia yang sangat sulit untuk diingkari. Kulit hitam dianggap tidak layak memenuhi standar kecantikan yang dominan di mana standar tersebut mempengaruhi harga diri dan citra diri seseorang dalam identitas budayanya. Standar kecantikan dominan bangsa Barat yang dikonstruksikan melalui media telah membangun diskriminasi di tengahtengah dunia yang penuh dengan pluralisme budaya.

Indonesia sendiri mengakui adanya suatu upaya pembudayaan yang bertujuan untuk "kemajuan adab, budaya persatuan, serta mempertinggi derajat kemanusiaan bangsa Indonesia"1

\footnotetext{
1 "Kebudayaan bangsa ialah kebudayaaan yang timbul sebagai usaha budidaya rakyat Indonesia seluruhnya. Kebudayaan lama dan asli yang terdapat sebagai puncakpuncak kebudayaan di daerah di seluruh
}

dengan memasukkan nilai-nilai kebudayaan asing. Dilihat dari sisi historis, upaya pembudayaan itu terjadi di masa kolonial (penjajahan) di mana kebudayaan Indonesia sebagai bangsa yang dijajah berkiblat pada kebudayaan Barat (penjajah), sejalan dengan itu, nasionalisme bangsa Indonesia juga berkiblat pada nasionalisme Barat. Simatupang (2002:21) menyebutkan bahwa dalam kerangka kebhinekaan, perlu dipertanyakan kedudukan budayabudaya etnis terutama yang jumlah pendukungnya sedikit (minoritas). Misalnya, apakah 'ketelanjangan' orang-orang di Papua perlu dipertahankan dan diperjualbelikan untuk konsumsi para turis dengan berpura-pura melestarikan budaya daerah?. Unsur-unsur budaya yang seperti itu, disebutkan oleh Simatupang, dijadikan 'penghuni semacam cultural $z o o$ '. Cultural zoo ini muncul dari upaya pembudayaan yang berlangsung selama masa kolonialisme dan secara tidak langsung, nilai rasis yang melekat pada budaya dan nasionalisme Barat pun ikut melekat dalam kebudayaan Indonesia, dan membuat dikotomi antara peradaban modern dan peradaban tradisional, antara ras kulit putih dan ras kulit hitam, antara mayoritas dan minoritas.

Iklan merupakan salah satu faktor kebudayaan yang paling penting yang mencetak dan merefleksikan kehidupan kita saat ini (Williamson, 2007:1). Apa yang ditampilkan di dalam iklan merupakan refleksi dari realitas budaya

Indonesia terhitung sebagai kebudayaan bangsa. Usaha kebudayaan harus menuju ke arah kemajuan adab, budaya persatuan, dengan tidak menolak bahan-bahan baru dari kebudayaan asing yang dapat memperkembangkan dan memperkaya kebudayaan sendiri, serta mempertinggi derajat kemanusiaan bangsa Indonesia" (Penjelasan UUD 1945, dikutip dari Simatupang, 2002:19) 
yang sedang terjadi dalam kerangka kebhinekaan Indonesia. Sebagai salah satu media tontonan, iklan menciptakan sebuah rangkaian tontonan yang diisi dengan berbagai tanda, citra dan makna (Piliang, 2003:289). Iklan merupakan tontonan yang kaya akan pesan semiotik, sehingga melalui iklan, nilai budaya saat ini telah menjelma menjadi industri.

Dalam iklan bermuatan budaya, etnis-etnis minoritas selalu dikontraskan dengan etnis mayoritas, dimarginalkan dan dijadikan sebagai komoditas yang dipertontonkan sebagai sebuah cultural zoo untuk tujuan komersial. Marginalisasi terhadap kelompok minoritas dilakukan oleh iklan dengan

\section{Tinjauan Pustaka}

Indonesia adalah suatu konsep kebudayaan baru. Sambil menyaksikan lahir dan jatuhnya kerajaan-kerajaan besar dan kecil selama berabad-abad, nusantara ini tidak pernah mengenal suatu kesatuan yang meliputi seluruh rangkaian kepulauan (Ibrahim, 1997:2930). Cikal bakal Indonesia berawal dari ikrar Sumpah Pemuda 1928 yang menyerukan sumpah berbahasa satu, bertanah air satu dan berbangsa satuIndonesia.

Kolonialisme memiliki peran penting dalam pembentukan Indonesia. Frantz Fanon dalam bukunya Black Skins, White Masks, mengatakan bahwa kolonialisme banyak diartikan sebagai penonmanusiawian (dehumanization) rakyat di daerah koloni. Orang-orang yang dijajah tidak diperlakukan sebagai manusia, tetapi lebih sebagai benda. Warna kulit hitam, cokelat atau kuning menunjukkan bahwa rakyat terjajah itu bukan hanya mereka yang kerjanya dirampas, tetapi juga mereka yang dalam jiwanya diciptakan inferioritas yang diakibatkan oleh kematian dan penguburan orisinalitas budaya lokal cara menghegemoni beragam ideologi yang disampaikan melalui mitos-mitos yang terdapat dalam sistem tanda iklan. Iklan cenderung mempertahankan etnis minoritas dengan citra yang 'hitam, polos, tradisional dan kuno'. Sosok etnis minoritas hanya sekedar diposisikan sebagai 'The Other' dalam iklan karena posisi superior tetap menjadi milik etnis mayoritas yang berkulit putih. Dengan demikian media mengabadikan posisi bangsa Indonesia, meminjam istilah Edward Said (dalam Sutrisno, 2005:61), sebagai "post colonial people": bangsa malang yang terus berada di bawah bayang-bayang kolonialisme.

mereka. Kompleks inferioritas ini ditanamkan dalam kesadaran budaya masyarakat koloni (Sutrisno dan Putranto, 2004:13). West dalam Brooks (1997:217) berpendapat, problematika tentang ketidaknampakan dan ketakbernamaan diaspora kulit hitam modern dapat dipahami sebagai kondisi dari relatif kurangnya kuasa kulit hitam untuk menghadirkan diri mereka sendiri untuk diri mereka sendiri dan orang lain sebagai makhluk hidup yang kompleks, dan dengan demikian untuk mempertandingkan bombardir stereotip negatif yang merendahkan yang dikemukakan oleh ideologi-ideologi supremasi kulit putih.

Menurut teori Post-Colonial, semua negara yang pernah dijajah tidak akan pernah mempunyai akar budaya yang murni, karena sistem penjajahan tidak hanya bersifat fisik melainkan juga secara mental dan ideologi. Kemudian berimbas pada kebudayaan mereka yang terpengaruh oleh budaya sang penjajah. Di masa pascakolonial, nasionalisme bangsa-bangsa pascakolonial (bekas jajahan) berkiblat pada nasionalisme Barat (penjajah). 
Istilah Post Colonial (Pascakolonial) mengacu pada baik era sesudah kolonialisme maupun pada sejumlah sikap kritis terhadap kolonialisme. Kondisi pascakolonial (postcolonial condition) merujuk pada kondisikondisi ketidakbebasan (Sutrisno \& Putranto, 2004:170).

Meskipun kolonialisasi telah berakhir, kolonialisasi adalah bagian dari konstruksi kebudayaan Indonesia (Prabasmoro, 2003:112). Indonesia sebagai bangsa yang pernah dijajah masih menyisakan kebudayaan yang identik dengan bangsa terjajah walaupun sudah melewati masa penjajahan tersebut. Budaya sebagai bangsa yang pernah terjajah memang menyisakan mental yang tidak bisa hilang dalam satu atau dua generasi setelah penjajahan. Ideologi yang mengatakan bahwa ras kulit putih yang lebih tinggi dibandingkan ras kulit hitam merupakan hasil konstruksi budaya yang terjadi selama kolonialisasi berlangsung.

Terminologi pascakolonial (postcolonial) tersebut menghasilkan problem multikulturalisme dalam sebuah negara di mana hubungan antara kelompok mayoritas (majority group) dan kelompok minoritas (minority group) menciptakan semacam kesenjangan, ketidakseimbangan, asimetri, dan ketidakadilan. Multikulturalisme adalah gerakan dalam memperjuangkan hubungan yang harmonis, berkeseimbangan, dan berkeadilan di antara kebudayaan mayoritas dan minoritas (Piliang, 2004:474). Mayoritas dan minoritas lahir dari pengalaman kolonial yang mengisahkan adanya penindasan dan diskriminasi terhadap "yang lain". Lukmantoro (2008) menyebutkan bahwa sejalan dengan pemikiran Anderson bahwa bangsa adalah komunitas yang dibayangkan ${ }^{2}$, maka televisi menjadi kekuatan yang menyediakan ruang dan waktu bagi perjumpaan anggota-anggota bangsa. Televisi menyajikan gambaran batasbatas teritorial bangsa kita dengan bangsa lain, dan persaudaraan di antara kalangan penonton yang mengidentifikasikan diri sebagai kita melawan mereka. Lebih dari itu, televisi disebutkan mempunyai kekuatan untuk menjalankan agenda tentang siapa saja yang menjadi musuh-musuh kita.

Akibatnya, iklan, sebagai produk kapitalisme media televisi, memungkinkan munculnya sebuah komunitas baru bangsa yang dibayangkan (a new imagined national community, Barker, 2000:199). Dalam hal ini, iklan memberi kontribusi dalam menciptakan imajinasi tentang siapa yang menjadi minoritas dan siapa yang menjadi mayoritas. Minoritas dianggap sebagai "yang lain" (the other) yang berbeda dengan minoritas, sehingga minoritas dianggap sebagai "musuh". Komunitas baru hasil bayang-bayang media ini bisa dikatakan merupakan kolonialisasi versi media. Apa yang ditampilkan iklan menciptakan realitas baru dalam ambiguitas, tentang hubungan mayoritas dan minoritas yang

\footnotetext{
${ }^{2}$ Bangsa, menurut pemikiran Bennedict Anderson, sesungguhnya merupakan komunitas yang dibayangkan (imagined community) (Barker, 2000:198). Dikatakan imagined community karena beberapa alasan. Pertama, bangsa dibayangkan karena masyarakatnya tidak pernah bertemu semuanya, bahkan dalam bangsa yang terkecil sekalipun. Kedua, bangsa dibayangkan terbatas karena bangsa yang sangat besar sekalipun memiliki wilayah yang terbatas. Ketiga, bangsa dibayangkan sebagai penguasa karena konsep bangsa muncul pada masa abad pencerahan untuk meruntuhkan bentuk pemerintahan kerajaan hirarki. Keempat, bangsa dibayangkan sebagai komunitas karena, dengan menghiraukan ketidaksamarataan dan eksploitasi, bangsa terbentuk sebagai sebuah hubungan persaudaraan.
} 
belum tentu terjadi dalam realitas multikulturalisme di Indonesia.

Selanjutnya, sejarah kolonialisasi memperkenalkan dua macam nasionalisme, yaitu nasionalisme Timur dan nasionalisme Barat. Dengan logika ini, Kita-Mereka (Us-Them) dibagi. Partha Chatterjee menyatakan bahwa nasionalisme Barat dianggap mampu menghasilkan model-model otonominya sendiri dari dalam, sementara nasionalisme Timur harus mengasimilasikan sesuatu yang lain ke dalam budayanya sendiri sebelum mereka menjadi bangsa-bangsa modern. Nasionalisme Timur, khususnya nasionalisme di negara-negara dunia ketiga, dipaksa untuk memilih antara menjadi dirinya sendiri atau menjadi bangsa-bangsa modern yang "sedang menjadi”, seolah-olah standar akal budi dan kemajuan universal pada hakikatnya dan secara intrinsik hanya ada pada Barat (Sutrisno \& Putranto, 2004: 108).

Dalam artikel "Western Nationalism and Eastern Nationalism: Is There A Difference that Matters?" (New Left Review 9, May-Jun 2001:33-34), Bennedict Anderson, penulis Imagined Communities (1983), mengatakan bahwa semua jenis nasionalisme tidak dapat dipahami tanpa bercermin pada masa lalu darimana nasionalisme itu muncul. Nasionalisme bangsa Indonesia lahir sebagai hasil adopsi dari nasionalisme Barat yang dibawa oleh negara penjajah. Pengalaman masa lalu sebagai bangsa yang terjajah akan terusmenerus membayangi bangsa Indonesia di masa depan. Sehingga sifat rasis terhadap kulit hitam yang melekat dalam nasionalisme Barat juga ikut diadopsi oleh Indonesia. Nasionalisme seperti ini, seperti yang disebutkan Anderson, adalah sebuah bentuk Creole Nationalism, dimana kata 'Creole' secara harafiah mengacu pada ras kulit putih. Merujuk pada penelitian Becoming White (Prabasmoro, 2003), hal ini mengakibatkan universalitas tubuh kulit dimana tubuh kulit putih dimaknai sebagai berbudaya dan sebagai kebudayaan, serta pada saat yang bersamaan sebagai beradab dan peradaban itu sendiri.

Peleburan nilai-nilai budaya tradisional Indonesia dengan budaya Barat yang tercampur aduk dalam Creole Nationalism menghasilkan 'wajah baru' dalam kebudayaan Indonesia. Indonesia harus menghadapi realitas lunturnya kebudayaan tradisional akibat banyaknya unsur-unsur kebudayaan luar yang diadopsi. Dalam kasus iklan bermuatan budaya ini, terlihat bagaimana universalitas ideologi nasionalisme Barat tersebut diadopsi oleh media dengan cara melakukan pemisahan, pembeda-bedaan etnis dan budaya dalam konteks klasifikasi rasial, hitam dan putih. Creole Nationalism mendorong Indonesia untuk berkeinginan mensejajarkan diri dengan bangsa-bangsa kulit putih yang sudah lebih maju. Media mempertontonkan bagaimana Indonesia, yang sepanjang sejarah selalu berusaha untuk mengejar identitasnya sebagai bangsa yang diakui dalam identitas ke-Barat-annya, yang berakibat pada tidak diakuinya identitas budaya minoritas dalam satu bagian dalam kebhinekaan.

Ketika Indonesia memasuki era reformasi dan ketika dunia telah berubah menjadi dunia tanpa batas (borderless world), kebudayaan mulai mendapat ruang gerak dalam media massa dan juga ikut menikmati kebebasan, akan tetapi media massa tidak pernah lepas dari intervensi oleh pemilik modal yang memiliki kepentingan ideologi dominan tertentu. Kapitalisme merupakan sebuah ideologi yang dominan, yang mengendalikan berbagai aspek kehidupan lainnya. 
Wibowo (2003:124) menyebutkan bahwa iklan berkiblat pada pemasaran, itu sebabnya, iklan senantiasa menggarisbawahi kepuasan konsumen-parameternya adalah meningkatnya penjualan. Media, dalam ideologi kapitalisme, terus menerus direduksi oleh materialisme, hedonisme, dan ekonomisasi sehingga nilai tukar material uang lebih berharga dari nilai harkat sesama manusia (Sutrisno \& Putranto, 2004:28). Nilai-nilai kebudayaan minoritas-yang dalam ideologi kapitalisme, dikemas secara sistematis dan strategis menjadi komoditi-akan kehilangan sifat integrasi dan keutuhannya, karena menjadi sasaran eksploitasi kebudayaan bagi satu tujuan yaitu keuntungan. Dibalik citra-citraan yang dibentuk media, media sesungguhnya mempertontonkan permainan hegemoni mengenai sosok etnis minoritas.

Ransome (dalam Strinati, 2009:255), mengatakan bahwa Gramsci menggunakan konsep hegemoni untuk menerangkan berbagai macam cara kontrol sosial bagi kelompok sosial yang dominan. Hegemoni bisa dilakukan dengan berbagai cara, termasuk melalui iklan. Muatan ideologi dalam hal ini berfungsi untuk memisrepresentasikan relasi simbolsimbol yang ada dalam iklan. Ideologi merupakan sebuah sistem di mana masyarakat memberikan pada dirinya sendiri suatu 'makna' yang berbeda dari dirinya yang sesungguhnya. Inilah yang disebutkan Judith Williamson sebagai 'sistem referen', yaitu titik dimana ideologi dan struktur-struktur simbolik atau penandaan bergabung membentuk sistem yang nyaris bersifat platonik di mana segala sesuatu bermakna sesuatu yang lain, dan tidak ada sesuatu pun yang merupakan dirinya apa adanya (Williamson, 2007:270,272).
Sistem referen, seperti yang dikemukakan oleh Williamson, merupakan sistem mitologis, yaitu 'realitas' eksternal yang dirujuk oleh sekumpulan tanda dalam sebuah iklan (Williamson, 2007:16). Sosok minoritas dalam iklan dalam hal ini dipahami sebagai sebuah sistem mitologis yang di baliknya terdapat berbagai realitas yang tersembunyi. Sehingga, nilai budaya etnis minoritas yang direpresentasikan oleh media, tatkala dikaitkan dengan kenyataan sosial, akan memunculkan problematika. Media tampaknya membiaskan realitas melalui sistem tanda dalam iklan. Representasi etnis minoritas dalam iklan tidak lagi sebatas keinginan untuk memperkenalkan kembali nilai-nilai budaya yang telah lama hilang, melainkan berubah menjadi bentuk manipulasi media terhadap realitas budaya di Indonesia.

\section{Metodologi Penelitian}

Penelitian ini menggunakan paradigma kritis, yang dikaji dari beragam pandangan dalam studi postcolonial di mana gagasan dominan berupa mitos dan ideologi yang terdapat dalam iklan dihubungkan dengan problematika sejarah bangsa Indonesia sebagai bangsa post-colonial. Tipe penelitian yang digunakan adalah deskriptif kualitatif dengan pendekatan analisis semiotika. Analisis semiotika digunakan untuk melihat bagaimana sistem tanda yang terdapat dalam iklan menghasilkan makna. Semiotika merupakan metode analisis yang digunakan untuk mengkaji tanda (teks, bahasa, gambar) yang terdapat dalam iklan-iklan bermuatan budaya.

Teknik analisis yang digunakan untuk membongkar ideologi dan mitos yang terdapat dalam iklan rumusan Ferdinand de Saussure mengenai cara pengorganisasian tanda ke dalam kode, yaitu analisis sintagmatik dan 
paradigmatik. Kedua cara pengorganisasian tanda ke dalam kode Saussure tersebut (sintagmatik dan paradigmatik), dipadukan dengan 3 (tiga) level kode televisi-nya John Fiske dalam buku Television Culture yang terdiri dari level realitas, representasi, dan ideologi. Iklan-iklan yang menampilkan sosok etnis minoritas akan dianalisis secara sintagmatik berdasarkan teknik analisis Television Codes-nya John Fiske pada level reality (realitas dilihat dalam bentuk penampilan, pakaian, make-up, lingkungan, perilaku, ucapan, gerakan, ekspresi, suara, dan sebagainya) dan representation (bagaimana realitas tersebut digambarkan melalui kamera, pencahayaan, editing, musik, dan suara). Analisis paradigmatik kemudian dilakukan pada level ideologi dengan menguraikan pola oposisi dalam iklan yang menyembunyikan makna, yang mengacu pada penampilan sosok etnisetnis minoritas yang terdapat dalam unit analisis.

\section{Hasil dan Pembahasan}

Diferensiasi minoritas dan mayoritas akan selalu menjadi perdebatan yang tak berakhir dalam bangunan multikultur negara Indonesia. Setiap iklan dalam unit analisis penelitian ini menunjukkan bahwa diferensiasi minoritas dan mayoritas adalah bersifat abadi, dalam bentuk apa pun itu, dan biasanya akan menghasilkan sebuah hubungan di mana mayoritas mendominasi minoritas.

Koteka dan sali dianggap sebagai bentuk ketelanjangan yang cacat, yang tidak dapat disamakan dengan estetika ketelanjangan orang Barat. Ketelanjangan dalam hal ini lebih dianggap 'hina', karena tubuh-tubuh yang telanjang tersebut dicampakkan iklan dalam sebuah parodi dengan alibi seni untuk dibandingkan dengan keberpakaian tubuh-tubuh endorser (Shanti, Donny, Chris John) yang dianggap mewakili peradaban Barat. Namun iklan sengaja mengisyaratkan seolah-olah ada hubungan yang baik antara tubuh-tubuh yang telanjang dengan tubuh-tubuh yang berpakaian tersebut. Iklan memperhalus pertunjukan tubuh telanjang ini dengan memperlihatkan wajah-wajah 'ramah' milik endorser, membuat mereka seolah-olah tampak menjadi bagian dari kehidupan Papua. Namun topeng 'ramah' yang digunakan endorser sebenarnya mengacu pada kesombongan, kecongkakan, dan kebanggaan atas keberpakaian diri mereka, yang pada akhirnya menyeret Papua ke dalam penelanjangan identitas diri.

Di sisi lain, ke"eksotis"an adalah bentuk pernyataan sekaligus pertanyaan atas keberadaan masyarakat etnis NTT yang sampai saat ini masih memelihara berbagai tradisi yang tampaknya sudah tidak lazim dilakukan di zaman modern ini. Sesungguhnya keberadaan masyarakat etnis NTT 'ditiadakan' ketika iklan mencampuradukkan mereka dengan endorser iklan (Shanti, Donny, Chris John, Rieke, dan Ade Rai) yang masing-masing dari mereka mencitrakan profesi modern yang berbeda-beda. Profesi endorser sebagai penyanyi, atlet, maupun aktivis tampaknya telah membuat masyarakat etnis NTT menjadi malu dengan diri mereka sendiri yang tidak mendapat pengakuan dalam dunia modern.

Sisi yang berbeda yang ditampilkan iklan mengenai NTT adalah menyangkut masalah kekeringan. NTT ditakdirkan sebagai daerah yang hampir selalu mengalami kekeringan di saat musim kemarau. Dalam iklan, takdir jugalah yang menentukan mereka untuk ditolong oleh bangsa Barat, seperti sebuah kisah 
klasik tentang pahlawan masa depan. Program "pengadaan air bersih" yang bertema 'Satu dari Kita, Sepuluh untuk Mereka' hanyalah kedok bangsa Barat untuk menyiratkan perlunya diadakan upaya pembersihan terhadap tubuhtubuh kotor yang mengacu pada masyarakat etnis NTT. Sesungguhnya tanah NTT memiliki air bersih, walaupun memang pada kenyataannya air bersih tersebut sulit didapat, namun bukan berarti tidak bisa didapat. Bangsa Barat, sebagai agen pembersihan ini, hanya melakukan sedikit upaya mengiring masyarakat etnis NTT agar lebih dekat dengan sumber pembersihan tersebut.

Iklan tampaknya memang lihai memainkan permainan yang bernama identitas. Pembandingan Nias, Sumba, dan Papua dengan Bali merupakan pembandingan yang tidak adil. Nias, Sumba dan Papua terpilih sebagai etnis yang mewakili identitas lokal sementara Bali terpilih untuk mewakili identitas global yang diperoleh sebagai warisan kolonial. Akhirnya yang terjadi adalah pengadu-dombaan etnis-etnis yang mengakibatkan lokalitas menjadi hilang ditelan globalitas. Wajah Indonesia dikerdilkan dan dimasukkan dalam citra Bali. Indonesia dalam hal ini tidak lagi diwakilkan melalui identitas lokal dalam lokalitas etnis-etnisnya, namun diwakilkan melalui identitas global dalam globalitas Bali. Bali menjadi tidak sepenuhnya Indonesia, namun juga tidak sepenuhnya Barat. Iklan hanya memanfaatkan Bali dengan memakaikan topeng kolonial Barat untuk menutupi identitas lokal Bali, yang ditujukan untuk menyenangkan hati bangsa Barat.

Kelihaian iklan terlihat pula dalam politik pecah belah yang diterapkannya dalam pembeda-bedaan antara daerah perbatasan dengan daerah pusat pemerintahan. Daerah perbatasan
Indonesia (Merauke, Pulau Dana, Sabang dan Pulau Miangas) dicitrakan terbalik dengan daerah pusat pemerintahan yang diwakilkan oleh Candi Borobudur. Candi Borobudur dalam ke-diam-an setumpuk batu yang tersusun rapi menyiratkan kemegahan dan keanggunan, berbelok menjadi kecongkakan dan keangkuhan ketika dibandingkan dengan daerah perbatasan. Sementara di sisi lain terlihat daerah-daerah perbatasan yang diwakilkan dalam tubuh anak-anak kecil yang tidak bisa diam, mereka mengisyarakatkan keinginan untuk bebas dari keterbatasan mereka sehingga akhirnya mereka pergi dari daerah asal mereka untuk merasakan kebebasan di daerah pusat pemerintahan. Iklan, dalam hal ini, mengabadikan kondisi kesenjangan sosial yang sudah menjadi bagian dalam bangsa yang hanya merupakan hasil imajinasi para pendiri yang tidak mampu menjamin kesejahteraan yang sama rata di tengah-tengah bangsanya.

$$
\text { Pada akhirnya, iklan }
$$

mengabadikan hal yang sama. Minoritas akan tetap menjadi minoritas sementara mayoritas akan menjadi mayoritas. Dan dalam konteks Indonesia, iklan mengukuhkan sebuah posisi dominan bagi etnis mayoritas bernama ernis Jawa dan Bali. Bahkan Maluku, daerah mesti$z o$ di mana masyarakatnya pada dasarnya merupakan masyarakat keturunan Eropa, tidak mampu menyaingi Jawa dan Bali karena dianggap sebagai indo yang cacat. Jawa dan Bali dianggap sebagai peradaban tertinggi di Indonesia, dengan konsekuensi bahwa peradaban di luar Jawa dan Bali adalah peradaban yang lebih rendah. Hubungan antara minoritas dengan mayoritas akan selalu menjadi dilema tak berakhir dalam negara multikultur ini. 
Keseluruhan unit analisis dalam iklan ini, mengandung sistem tanda yang di dalamnya terdapat beragam mitos mengenai ke-telanjang-an, tradisi, ke-bersih-an, identitas ke-indo-an, dan kebangsaan, yang pada akhirnya mengarah pada hubungan dominansi mayoritas terhadap minoritas. Mitosmitos tersebut berkiblat pada ideologiideologi yang berasal dari sejarah masa lalu yaitu kolonialisasi yang mengacu pada ideologi kelas, ras, dan bahasa dengan hubungan sebagai berikut: identitas etnis dengan ras kulit putih (dalam hal ini diartikan sebagai orangorang yang mewakili bangsa Barat/penjajah) dalam bingkai pluralitas etnis di Indonesia dianggap memiliki derajat kelas sosial yang lebih tinggi, memunculkan homogenisasi dan standarisasi bahasa, yang pada akhirnya semua itu merupakan [obsesi] kolonial yang diadopsi oleh media untuk menciptakan sebuah bangsa hasil imajinasi di mana etnis mayoritas diposisikan sebagai peradaban yang lebih tinggi untuk mendominasi etnis minoritas demi kepentingan kapitalisme.

\section{Kesimpulan}

1. Salah satu warisan kolonial yang ikut diadopsi iklan adalah sifat rasis bangsa Barat yang mengarah pada perlakuan diskriminasi berdasarkan dikotomi kulit hitam dan kulit putih. Akibatnya iklan merepresentasikan marginalisasi etnis minoritas yang dilakukan oleh etnis mayoritas. Etnis minoritas sesungguhnya hanya dijadikan badut-badut kepunyaan etnis

\section{Daftar Pustaka}

Abdullah, Irwan. (2006). Konstruksi dan Reproduksi Kebudayaan. Yogyakarta: Pustaka Pelajar mayoritas yang bisa diperlakukan dengan seenaknya.

2. Iklan tidak pernah bebas nilai. Pola oposisi yang terkandung di dalam iklan pada akhirnya mempermalukan etnis-etnis minoritas bersamaan dengan kebudayaannya yang dikumpulkan dalam sebuah tontonan cultural zoo untuk dinikmati oleh masyarakat multikultural Indonesia.

3. Etnis-etnis minoritas dianggap tidak berbudaya, tidak beradab, primitif, dan sebagainya, sehingga terhadap etnis-etnis minoritas tersebut dianggap perlu dilakukan suatu upaya pembudayaan yang sebenarnya justru semakin merendahkan dan mengacaukan identitas kultural etnis minoritas.

4. Sosok etnis-etnis minoritas dalam iklan merupakan cerminan kehidupan berbangsa di Indonesia, di mana bangsa Indonesia tampaknya menjadi bangsa yang mendiskriminasi bangsanya sendiri. Etnis-etnis minoritas ditampilkan bukan untuk mengangkat nilai budaya mereka atau untuk menghargai perbedaan kultural, melainkan untuk memarginalkan mereka. Hampir tidak ada lagi pengakuan akan perbedaan di negara yang menjunjung tinggi persatuan ini. Minoritas akan tetap menjadi minoritas, dan di sisi lain, mayoritas akan tetap menjadi mayoritas. Yang tersisa hanyalah sebuah sejarah yang menyatakan bahwa bangsa ini, dahulu, pernah benar-benar bersatu.

Amalia, Lia. (2009). Mitos Cantik di Media. Ponorogo: STAIN Ponorogo Press

Barker, Chris. (2000). Cultural Studies: Theory and Practice. London: Sage Publications 
Brooks, Ann. (1997). Post Feminisme and Cultural Studies: Sebuah Pengantar Paling Komprehensif. Yogyakarta: Jalasutra

Ibrahim, Idi Subandy. (1997). Lifestyle Ectasy: Kebudayaan Pop dalam Masyarakat Komoditas Indonesia. Yogyakarta: Jalasutra

Marzali, Amri. (2005). Antropologi dan Pembangunan Indonesia. Jakarta: Prenada Media

Piliang, Yasraf Amir. (2003). Hipersemiotika: Tafsir Culturas Studies Atas Matinya Makna. Yogyakarta: Jalasutra

Piliang, Yasraf Amir. (2004). Dunia Yang Dilipat: Tamasya Melaumpaui Batas-batas Kebudayaan. Yogyakarta: Jalasutra

Prabasmoro, Aquarini Priyatna. (2003). Becoming White: Representasi Ras, Kelas, Feminitas dan Globalitas dalam Iklan Sabun. Yogyakarta: Jalasutra

Simatupang, Maurits. (2002). Budaya Indonesia yang Supraetnis. Jakarta: Papas Sinar Sinanti

Strinati, Dominic. (2009). Popular Culture: Pengantar Menuju Teori Budaya Populer. Yogyakarta: ArRuzz Media

Sutrisno, Mudji dan Putranto, Hendar (Eds). (2004). Hermeneutika
Pascakolonial: Soal Identitas. Yogyakarta: Kanisius

Sutrisno, Mudji dan Putranto Hendar. (2005). Teori-Teori Kebudayaan. Yogyakarta: Kanisius

Wibowo, Wahyu. (2003). Sihir Iklan: Format Komunikasi Mondial dalam kehidupan Urbankosmopolit. Jakarta: Gramedia Pustaka Utama

Williamson, Judith. (2007). Decoding Advertisements: $\quad$ Membedah Ideologi dan Makna dalam Periklanan. Yogyakarta: Jalasutra

\section{Artikel:}

Anderson, Bennedict. (2001, MayJune). Western Nationalism and Eastern Nationalism: Is There A Difference that Matters?. New Left Review 9.

Lukmantoro, Triyono. (2008, Juni 27). Menikmati Tontonan Nasionalisme Melodrama. Suara Merdeka.

\section{Sumber internet:}

Hamzah, Herdiansyah. A Girl Like Me: Diskriminasi Ras Kulit hitam. Dalam http://www.herdiansyah.org/2010/ 03/girl-like-me-diskriminasi-raskulit.html diakses pada 1 Juni 2010 pukul 09.50 WIB 
